Armağan Böğürcü,

Ali Ekinci,

Murat Alyakut,

Ali Berkant Avcı

\section{Difüz Alveoler Hemoraji ve Solunum Yetmezliği ile Seyreden Wegener Granülomatozu}

\author{
Wegener's Granulomatosis Accompanied by Diffuse \\ Alveolar Hemorrhage and Respiratory Failure
}

Geliş Tarihi/Received: 21.05.2013

Kabul Tarihi/Accepted: 01.11.2013

Türk Yoğun Bakım Derneği Dergisi, Galenos Yayınevi tarafından basılmışıır.

Journal of the Turkish Society of Intensive Care, published by Galenos Publishing.

ISNN: 1300-5804

Armağan Böğürcü $(\bowtie)$, Murat Alyakut,

Özel OFM Antalya Hastanesi Yoğun Bakım Ünitesi,

Antalya, Türkiye

Ali Ekinci,

Özel OFM Antalya Hastanesi Göğüs Hastalıkları

Kliniği, Antalya, Türkiye

Ali Berkant Avcl,

Akdeniz Üniversitesi Tıp Fakültesi lç Hastalıkları

Anabilim Dalı Romatoloji Bilim Dalı, Antalya, Türkiye
ÖZET Difüz alveoler hemoraji ile seyreden Wegener granülomatozu, nadir görülen ve hayatı tehdit eden bir hastalıktır. Subjektif pek çok şikâyet bir arada değerlendirilerek, tanının hızla konulması ve tedaviye bir an önce başlanması gereklidir. Bu çalışmada, 39 yaşındaki bir erkek olgunun hastalığın semptomlarının ortaya çıkmasından tanı konulmasına kadar geçen sürede karşılaştığı değişik ayırıcı tanı ve tedavi uygulamaları vurgulanarak, mortal seyreden bu hastalığa karşı daha dikkatli davranmak gerektiğine dikkat çekmek amaçlanmıştır.

Anahtar Kelimeler: Difüz alveoler hemoraji sendromları, Wegener granülomatozu, c-ANCA

\begin{abstract}
SUMMARY Wegener's granulomatosis accompanied by diffuse alveolar hemorrhage is a rare and life-threatening disease. Diagnosis should be established rapidly by evaluating many subjective complaints together and the treatment should be performed as soon as possible. In this case, various differential diagnosis and treatment applications which were performed in 39-year-old male patient within the period beginning from the onset of symptoms of the disease to establishment of the diagnosis were emphasized and it was aimed to highlight the fact that this mortal disease requires more attention.
\end{abstract}

Key Words: Diffuse alveolar hemorrhage syndromes, Wegener's granulomatosis, c-ANCA

E-posta: armagan99@hotmail.com

Tel.: +902423203000

\section{Olgu}

Otuz dokuz yaşındaki erkek olgu, yaklaşık 10 gün önce öksürük ve az miktarda kanlı balgam şikâyetleri ile özel bir hastaneye başvurmuş. Atipik pnömoni düşünülen olgu hastaneye yatırılip parenteral moksifloksasin tedavisi başlanmış. Bir haftalık tedavi sonrasında kliniğinde düzelme olmaması üzerine başka bir hastaneye sevk edilen olgunun takibi sırasında nefes darlı̆ında artış ve kan oksijen $\left(\mathrm{O}_{2}\right)$ satürasyonunda düşüş sonucu yoğun bakım ihtiyacı nedeni ile hastanemiz yoğun bakım ünitesine kabul edildi. Anamnezinde 20 gündür öksürük, kanlı balgam, gece terlemeleri, kilo kaybı ve hâlsizlik olduğunu belirten olgunun tedavisine, yoğun bakımın ilk gününde enfeksiyon hastalıkları, göğüs hastalıkları ve iç hastalıkları konsültasyonlarının ardından atipik pnömoni olarak devam edildi. Arteriyel kan gazı $\mathrm{pH}: 7,40, \mathrm{PaCO}_{2}: 36 \mathrm{mmHg}$, $\mathrm{PaO}_{2}: 69 \mathrm{mmHg}, \mathrm{O}_{2}$ satürasyonu \%90 olarak değerlendirilen olgu, nazal $\mathrm{O}_{2}$ ve iki saatte 10 dakika "continuous positive airway pressure (CPAP)" yapılarak takip edildi. Olgunun akciğer grafisinde ise yamalı infiltrasyonlar görüldü (Şekil 1). 
Hemoglobin değeri 9,3 g/dL saptanan ve idrarda bol eritrosit mevcut olan olgunun pıhtılaşma testleri, platelet ve romatoid faktör (RF) değerleri normal düzeyde idi. Ayırıcı tanılarda, mesleğinin aşçılık olması nedeni ile Brucella, Legionella, tüberküloz (Tbc), Tropenoma pallidum gibi nedenler dışlandı. Takibin üçüncü gününde olgunun kliniğinde düzelme olmadl; hemoglobin değeri 7,4 g/dL'ye düştü, kan O2 satürasyonu ise $\% 90$ civarında idi. Dördüncü gün toraks bilgisayarlı tomografi (BT) ve batın BT görüntülemesi yapıldı (Şekil 2).

Olgunun her iki akciğerinin hemen tüm alanlarında yamalı tarzda, alveoler; yer yer buzlu cam görünümünde yer yer konsolidasyon tarzında yoğunluk artımları görüldü. Bu alanlar çevresinde retikülonodüler tarzda interstisiyel kalınlaşmalar ve subsegmenter bronş duvarlarında difüz kalınlaşmalar izlendi. Beşinci gün bronkoskopi yapıld;; bronkoalveoler lavaj

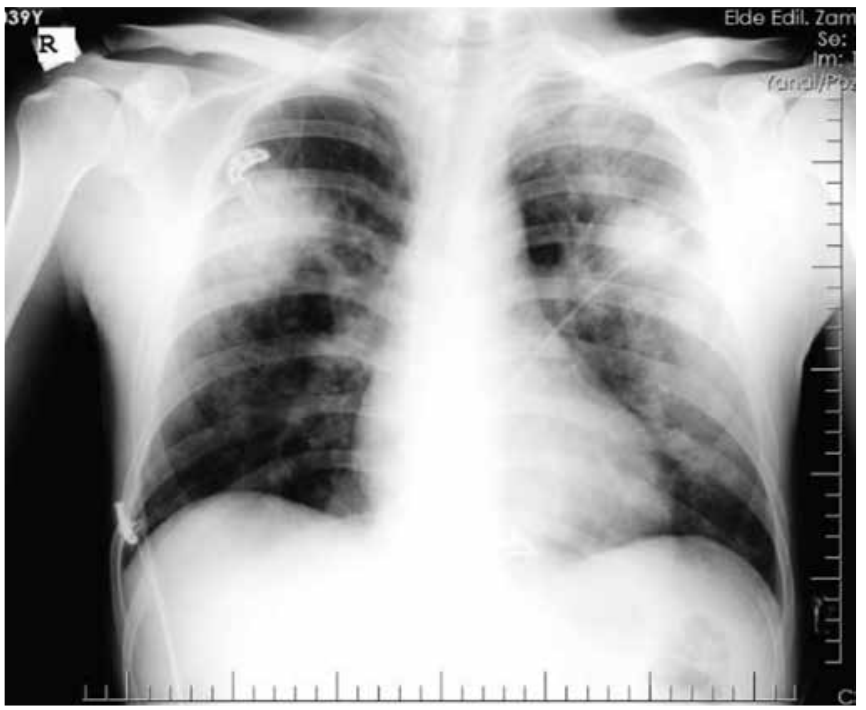

Şekil 1. Olgunun akciğer grafisi

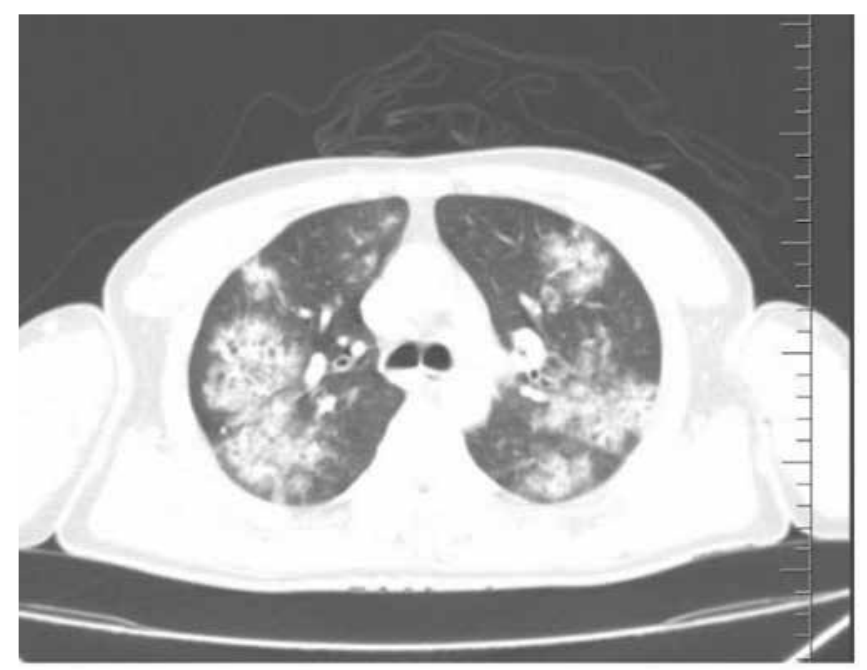

Şekil 2. Olgunun toraks bilgisayarlı tomografi görüntüleri
(BAL) sIVISında bakılan aside rezistan basil negatif saptandı. Kültüründe üreme olmayan olgunun sitoloji ve transbronşiyal biyopsi patolojilerinden spesifik bir tanıya ulaşılamadı, ancak hematüri gözlendi. Hemoglobin değeri $6,8 \mathrm{~g} / \mathrm{dL}$ olarak ölçüldü ve $3 \mathrm{U}$ eritrosit süspansiyonu ile $1 \mathrm{U}$ taze donmuş plazma verildi. Genel durum bozulduğu ve alınan arteriyel kan gazı $\mathrm{pH}: 7,43, \mathrm{PaCO}_{2}: 34 \mathrm{mmHg}, \mathrm{PaO}_{2}: 38 \mathrm{mmHg}$ olduğu için olgu entübe edilerek mekanik ventilatör (MV) desteğine alındı ve difüz alveoler hemoraji sendromu tanısı ile pulse steroid tedavisi başlandı. Sedasyonla MV desteğinde takip edilen olgunun yedinci gününde romatolojik test sonuçları geldi. Anti nötrofil sitoplazmik antikor (c-ANCA) pozitif gelmesi üzerine tedaviye siklofosfamid eklenmek istendi, ancak Sağlık Uygulama Tebliği (SUT) 2013'te "Siklofosfamid yalnızca kanser hastalarında uygulanır." ibaresi nedeni ile verilemedi. Alternatif olarak tedaviye azatioprin eklendi. Olgunun Akdeniz Üniversitesi Tıp Fakültesi lç Hastalıkları Romatoloji Yoğun Bakım Ünitesine sevki planlanarak, 10. gün sevk edildi. Tedaviye siklofosfamid ile devam edildi, ilerleyen günlerde plazmaferez yapılmaya başlandı. Tedavi süresince hemoptizi devam etti ve olgu MV desteğinde takip edildi. Ancak, sekonder enfeksiyonlar ve sepsis nedeni ile tedavinin üçüncü, hastalık seyri başlangıcının altıncı haftasında kaybedildi.

\section{Tartışma}

Alveoler hemoraji sendromları, alveoler, kapiller harabiyete bağlı difüz alveoler kanama ile karakterize bir grup hastalıktır. En sık nedeni vaskülitlerdir (5).

Alveoler boşluğa yaygın kanama sonucu dispne, hemoptizi, anemi ve akciğer grafisinde bilateral alveoler konsolidasyonlara yol açar. Alveoler septa harabiyeti immün mekanizmalara, toksik ajanlara maruziyete bağlı olabileceği gibi bazen sebebi bulunamayabilir (5).

Difüz alveoler kanama sıklıkla alveoler kapillerden kaynaklanır. Histolojik olarak kapillerit bulunup bulunmamasına göre sınıflandırıır. En sık sebepleri arasında:

Kapillerit bulunanlar; Wegener granülomatozu, mikroskobik polianjiit, izole pulmoner kapillerit (ANCA pozitif veya negatif), sistemik lupus eritematozis (SLE), romatoid artrit (RA), HenochSchonlein purpurası, Behçet hastalığı, immünglobulin A (lgA) nefropatisi, Goodpasture sendromu, retinoikasit toksisitesi, difenilhidantoin toksisitesi, ülseratif kolit, propiltiourasil toksisitesi sayılabilir.

Kapillerit bulunmayanlar; koagülasyon bozuklukları, ekzojen ajanlara maruz kalma (izosiyanat, penisilamin, amiodaron, nitrofurantoin, kokain inhalasyonu, radyasyon tedavisi), mitral stenoz, subakut bakteriyel endokardit, multipl miyelom, pulmoner venooklüziv hastalıklar, pulmoner damarsal ve metastatik tümörler sayılabilir (5). 
Alveoler hemoraji tanısında en değerli yöntem BAL'dır. Birçok segmentte kanlı sıvının sızdığı görülür. BAL sıvısında hemosiderin yüklü makrofajların \%30'dan fazla olması kronik hemoraji varlığını gösterir (5).

Hastalar vaskülit yönünden araştırılmalı, sinovit, periferik nöropati ve derin ven trombozu varlığı yönünden değerlendirilmelidir. Proteinüri veya anormal idrar sedimenti varlığı glomerülonefrit göstergesi olabilir. Goodpasture sendromu, SLE ve Wegener granülomatozuna yönelik serolojik araştırmalar yapılımalıdır (5).

Transbronşiyal biyopsi ile eğer yeterli materyal alınabilirse pulmoner kapillerit gösterilebilir. Renal tutulum saptanan olgularda böbrek biyopsisi tanı koydurabilir (5).

Wegener granülomatozu, üst ve alt solunum yollarının nekrotizan granülomatöz inflamasyonu ile ilişkili multisistemik tutulum yapan bir vaskülit sendromudur. Her yaş grubunda rastlanabilir. Hastaların \%99'unda kulak burun boğaz tutulumu vardır. Epistaksis, kronik rinit, sinüzit, otit, jinjival peteşi ve hipertrofiler görülebilir. Yine \%95 oranında akciğer tutulumu vardır. Lezyonlar multipl, nodüler, nekrotizan ve granülomatözdür; \%80 böbrek tutulumu, fokal segmental glomerülonefrit; \%50 deri bulguları peteşi ve purpuralar; \%40 sinir sistemi tutulumu, periferik nöropati sık görülür; $\% 10$ oranında ise göz tutulumu, konjonktivit, sklerit ve korneal ülserler görülebilir. Akciğer grafisinde kaviteli veya kavitesiz nodül veya kitle karakteristiktir. Bronkoskopik biyopsi hastaların \%20'sinde Wegener granülomatozu tanısı koydurur; klinik ve serolojik bulgular birleştiğinde bu oran $\% 50$ 'ye yükselir. c-ANCA düzeyleri tanı ve takipte kullanılır. Wegener granülomatozunda nötrofillerde bulunan azurofilik granül içindeki proteinaz-3 için spesifik olan c-ANCA \% 85-90 pozitiftir (sensitivite \%65, spesifisite \%98). Miyeloperoksidaz için spesifik olan p-ANCA ise ancak $\% 5$ pozitiftir. Kesin tanı vaskülitin histopatolojik olarak gösterilmesi ile konur (1-3).
Ayırıcı tanıda en sık mikroskobik polianjiit ile karışır. Küçük damarları etkileyen ve immün depozit yapmayan nekrotizan vaskülit olarak tanımlanır. Erkeklerde en sık beş ve altıncı dekadlarda; \%90 böbrek tutulumu, sıklıkla nekrotizan glomerülonefrit şeklinde görülür, \%62 deri, \%58 periferik sinir, \%30 gastrointestinal sendrom, \%22-29 akciğer tutulumu gözlenir. Akciğer tutulumunda kapillerit mevcuttur. Akciğer grafisinde bilateral konsalidasyon gözlenir, en sık BT bulgusu \%94 ile buzlu cam görünümü, \%78 ile konsalidasyondur. c-ANCA \%75 pozitiftir, çoğunlukla p-ANCA da pozitiftir. Tedavisi Wegener granülomatozu ile aynıdır (4).

Goodpasture sendromunda böbrek ve akciğerler aynı anda tutulur (\%60-80); alveoler ve glomerüler bazal membran antikorları saptanır. Anti bazal membran antikorları Tip 4 kollajenin alfa-3 bölümüne karşı oluşur. Tedavi Wegener granülomatozu ile benzerdir (3).

Wegener granülomatozunun tedavisinde prednizon ve siklofosfamid ilk seçenektir. Bazı hastalarda siklofosfamid yerine metotreksat kullanılabilir. Immünsupresiflere yanıt vermeyen vakalarda plazmaferez, anti-ANCA antikorları içeren immünglobulinler veya anti-TNF'ler denenebilir (1-3).

\section{Sonuç}

Wegener granülomatozunda, difüz alveoler hemoraji hastalığın diğer bulgularından önce ortaya çıkabilir ve agresif tedaviye rağmen mortal seyredebilir. Erken doğru tanı, yüksek doz kortikosteroid, sitotoksik ajanlar, bazen plazmaferez yararlı olabilir. Yoğun bakım doktorları, özellikle difüz akciğer parankimal anormalliklerinin, pulmoner kanamanın, açıklanamayan aneminin ve açıklanamayan kan kaybı birlikteliklerinde kollajen vasküler hastalık semptomlarının klinik belirtilerini akıllarına getirmelidirler.

\section{Kaynaklar}

1. Schwarz MI,King TE.Interstitial Lung Disease. 4Th ed. London:BC Decker,2003

2. Erdoğan $Y$,Samurkaşoğlu B.Diffüz Parenkimal Akciğer Hastalıkları.1. Baskı. Ankara:Mesut Matbaacılık,2004
3. Maffessanti M,Dalpiaz G.Diffüse Lung Diseases.1st ed. Milan:Springer,2006

4. Collins CE, Quismorio FP Jr. Pulmonary Involvement in Microscopic Polyanjiitis. Curr Opin Pulm Med 2005;11(5):447-51.

5. Akciğer Hastalıkları Temel Bilgiler .Türk Toraks Derneği Okulu Kitabı 